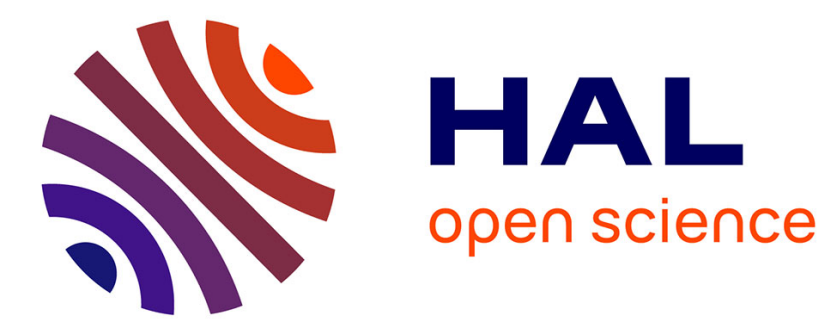

\title{
Decentralize, adapt and cooperate
}

Rafe Sagarin, Candice Alcorta, Scott Atran

\section{To cite this version:}

Rafe Sagarin, Candice Alcorta, Scott Atran. Decentralize, adapt and cooperate. Nature, 2010, 465, pp.292-293. ijn_00505192

\section{HAL Id: ijn_00505192 \\ https://hal.science/ijn_00505192}

Submitted on 22 Jul 2010

HAL is a multi-disciplinary open access archive for the deposit and dissemination of scientific research documents, whether they are published or not. The documents may come from teaching and research institutions in France or abroad, or from public or private research centers.
L'archive ouverte pluridisciplinaire HAL, est destinée au dépôt et à la diffusion de documents scientifiques de niveau recherche, publiés ou non, émanant des établissements d'enseignement et de recherche français ou étrangers, des laboratoires publics ou privés. 


\title{
NATURE | OPINION
}

\section{Decentralize, adapt and cooperate}

\author{
Raphael D. Sagarin, Candace S. Alcorta, Scott Atran, Daniel T. Blumstein, Gregory P. \\ Dietl, Michael E. Hochberg, Dominic D. P. Johnson, Simon Levin, Elizabeth M. P. \\ Madin, Joshua S. Madin, Elizabeth M. Prescott, Richard Sosis, Terence Taylor, John \\ Tooby \& Geerat J. Vermeij
}

Nature 465, 292-293 (20 May 2010) doi:10.1038/465292a

Published online 19 May 2010

\section{Two years ago Raphael D. Sagarin and colleagues proposed that security systems should learn from nature. Now they've worked with defence professionals on putting that call into practice.}

Humankind faces a wide range of threats to its security and safety, from terrorist groups and cybercriminals to disease pandemics and climate change. All these threats share one characteristic: they are constantly changing. Decision-makers can never be sure whether the next tropical storm will be as violent as the last, or whether Taliban insurgents will use a roadside improvised explosive device or a suicide bomber for their next attack. Therefore, many of our security systems - those that are resistant to change, or that try to eliminate all risk - are doomed. Firewalls have failed to protect computers from hackers for 40 years; screening airline passengers for liquids didn't prevent Umar Abdulmutallab from taking a powdered incendiary onto a plane; and so cumbersome is the military procurement cycle that heavy armoured vehicles designed to repel improvised explosive attacks were deployed in Iraq a full three years after soldiers had identified the need.

The world needs a new way to deal with constantly shifting threats. Two years ago we suggested in our book Natural Security: A Darwinian Approach to a Dangerous World (Univ. California Press, 2008) that the best place to look for such an approach is the natural world, because the security issues of modern human societies are analogous to those of many organisms. In nature, risks are frequent, variable and uncertain. Over 3.5 billion years, organisms have evolved an enormous variety of methods to survive, grow and proliferate on a continually changing planet. The key to their success is adaptability - the capacity to change structures, behaviours and interactions in response to selective pressures.

To explore how 'natural security' could apply in practice we 
have now worked with many people — including emergency management coordinators, cybersecurity experts, soldiers, police chiefs, air marshals, homeland security officials, fire chiefs and public-health officials. We have identified several features of natural systems that we
"The most potent biological analogy for human security is the immune system." believe would translate well to human security. These are common patterns and behaviours in natural systems that have probably evolved independently many times and have proved successful against a range of threats. We have analysed many human situations that would benefit from natural security, and several that already have. Although other researchers have used ecological models to analyse patterns of violence during conflicts ${ }^{1}$, we believe that using natural and social-science methods to look at the broad spectrum of human-security concerns will lead to more adaptable and effective defences.

\section{Embrace uncertainty}

One of our key observations is that the most adaptable and successful organisms largely avoid centralization. They devolve powers of detection and responses to environmental change to several independent sensory mechanisms, such as specialized organs or clusters of nerve cells. Octopuses, for example, use networks of pigment cells to match the colour of their surroundings. Clonal organisms such as corals distribute tasks, including feeding, reproduction and defence, among clones depending on the local need.

Certain human organizations have already recognized the advantages of this approach. Some of the most lethal modern terrorist groups are loosely organized, virtually leaderless and capable of causing huge disruption at low material cost — the 11 September 2001 attacks cost al-Qaeda about US $\$ 400,000$. Google drives the development of many of its products by encouraging Internet users to test them out, and some of its products feed off user activity. Google Flu Trends analyses search terms to provide accurate indications of flu outbreaks up to two weeks before the US Centers for Disease Control and Prevention in Atlanta, Georgia².

Most security measures are designed by a small number of experts and implemented by a central authority. But some agencies have demonstrated that decentralization is easy and effective. In 2004, the US Defense Advanced Research Projects Agency funded a competition to build a driverless vehicle that could navigate an obstacle course. Of the 15 vehicles that entered, none finished the course, yet the groups learned from each other and modified their designs so that the next year all but one of the cars that started got further than the previous year's winner, and five completed the race. The next race was even more 
successful, with competitors negotiating a more sophisticated urban environment and responding to traffic laws and other vehicles.

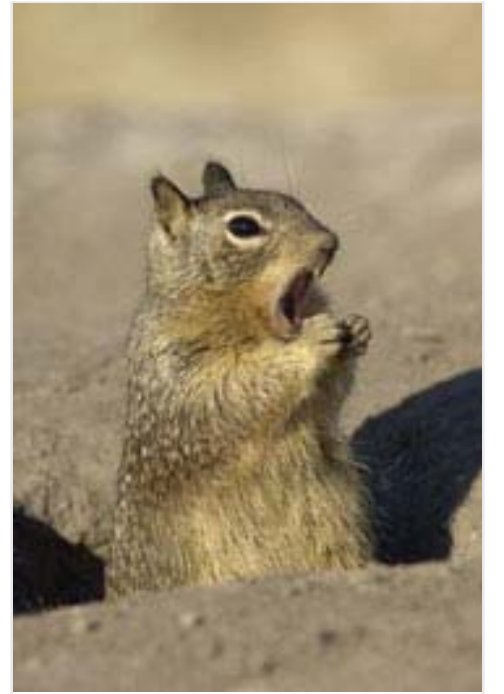

M. SCHUYL/FLPA

Ground squirrels deter different predators with calls, moves and tailheating.
Another feature of natural systems that governments could adopt is the capacity to reduce uncertainty or capitalize on it. In nature, predators can create uncertainty by stalking prey from concealed positions. Their prey may reduce it by signalling the presence of predators to others. To be effective, this signalling must be specific to particular threats. For example, ground squirrels make vocal signals to deter bird and mammal predators that can hear, but switch to silent tail-flagging displays to deter snakes that cannot hear, and heat their tails when confronted by snakes such as pit vipers that can sense infrared ${ }^{3}$. By contrast, individuals that make constant, ambiguous alarm calls only increase uncertainty for other members of their group, who must waste resources determining whether the alarm is genuine ${ }^{4}$.

The US Homeland Security's threat advisory for national and international flights ignores this principle: it has remained at level orange (high) since August 2006. This static, ambiguous and

nonspecific system creates uncertainty, or indifference, among the population that it is meant to help protect. An alternative approach could be to screen passengers for irregular behaviours or facial expressions that might betray ill intentions. This could work against different types of threat - terrorists or drug-smugglers, for example — and return control of uncertainty to the security services because it could be conducted from hidden vantage points or by video. Although the effectiveness of behavioural profiling is questionable, it has robust evolutionary underpinnings in that facial and behavioural-pattern recognition is widespread in social organisms including humans. Moreover, studies have shown that people can quickly learn to recognize facial expressions that betray particular emotions ${ }^{5}$.

Just as crucial for survival — and relevant for human security — is the capacity to cooperate with other organisms to exploit resources and environments. Symbiosis is ubiquitous in nature and takes many forms. For example, blue-ringed octopuses have toxin-producing bacteria in their salivary glands, making them more formidable predators. This cooperation lesson was demonstrated in Iraq in 2007, when General David Petraeus's strategy to form alliances with local leaders — including those who had been hostile — resulted in more tipoffs about improvised explosive devices and fewer American casualties. 


\section{ALLERUZZO/AP PHOTO}

General David Petraeus's alliances with local leaders in Iraq resulted in fewer American casualties.

One of us (Taylor) is involved with another example of successful symbiosis: the Middle East Consortium on Infectious Disease Surveillance (MECIDS; http://www.mecids.org), which promotes collaboration between Israelis, Palestinians and Jordanians to prevent the spread of infectious diseases and food-borne illness. These efforts have led to networks of health professionals that have emerged not because they were mandated by government or international treaty, but as local, adaptive responses to the need to protect food supplies and human health from pathogens that do not recognize international borders.

The MECIDS network encapsulates the three essentials of natural security: decentralized organization, the flexibility to adapt to uncertainty and symbiotic interaction. These features greatly enhance the capacity of any of the member states to tackle outbreaks alone. Furthermore, although the network was not designed to address the much more complex issue of promoting peace in the region, it undoubtedly spurs wider cooperation by necessitating sustained dialogue between senior officials from foreign affairs, security, agriculture, immigration, customs and other government departments ${ }^{6}$.

\section{Evolve to thrive}

Nature's approaches to security are enormously diverse, and therefore worthy of more scrutiny. To help us manage a diversity of risks, we need to address why certain adaptations arise in nature at particular times and places: are they the result of repeated interactions, a response to chronic stress or a way of coping with constant natural variation? Studying the myriad examples of apparently well-adapted organisms that went extinct is another area that can potentially inform us about catastrophic failures in our own security systems.

Translating ideas from nature into usable security solutions is complex. It requires sensitivity to the differences and similarities between human societies and other evolutionary systems. For example, fundamentalist behaviours at the core of many security problems make more sense when viewed as deeply rooted evolutionary biases towards strengthening group identity against outsiders, which cannot be easily manipulated through material negotiations ${ }^{7}$,

8. We are not proposing the wholesale replacement of human security systems with biological models. Rather, we are arguing for a series of deliberate interventions aimed at improving a system's adaptability. As with any science-based approach, many considerations will determine how it is applied, including ethics, politics, budgets and value-systems. 
The most potent biological analogy for human security is the immune system, which shifts from early, generalized responses to more adaptive responses as pathogens become more threatening. Encouragingly, one major security organization seems to be moving towards this approach. The US Transportation Security Administration launched a blog in 2008 to encourage greater interaction and dialogue with air travellers under the slogan, "Terrorists Evolve. Threats Evolve. Security Must Stay Ahead. You Play a Part". Hopefully this is not a flash in the pan, but part of a general acceptance that societies must adapt to survive and be successful.

\section{References}

1. Bohorquez, J. C., Gourley, S., Dixon, A. R., Spagat, M. \& Johnson, N. F. Nature 462, 911-914 (2009).

2. Ginsberg, J. et al. Nature 457, 1012-1014 (2009).

3. Rundus, A. S., Owings, D. H., Joshi, S. S., Chinn, E. \& Giannini, N. Proc. Natl Acad. Sci. USA 104, 14372-14376 (2007).

4. Blumstein, D. T., Verneyre, L. \& Daniel, J. C. Proc. R. Soc. Lond. B 271, 1851-1857 (2004).

5. Endres, J. \& Laidlaw, A. BMC Med. Educ. 9, 47 (2009).

6. Gresham, L., Ramlawi, A., Briski, J., Richardson, M. \& Taylor, T. Biosecur. Bioterror. 7, 399-404 (2009).

7. Hochberg, M. E. Proc. R. Soc. Lond. B 271, S313-S316, (2004).

8. Atran, S., Axelrod, R. \& Davis, R. Science 317, 1039-1040 (2007).

Download references

\section{Author information}

\section{Affiliations}

Raphael D. Sagarin is at the Institute of the Environment, University of Arizona, Tucson, Arizona 85716, USA.

rafe@email.arizona.edu

Candace S. Alcorta is in the Department of Anthropology, University of Connecticut, Storrs, Connecticut 06269-2176, USA.

Scott Atran is at the CNRS, Institut Jean Nicod-Ecole Normale Supérieure, 29 rue 
d'Ulm, 75005 Paris, France

Daniel T. Blumstein is in the Department of Ecology \& Evolutionary Biology, University of California at Los Angeles, 621 Charles E. Young Drive South, Los Angeles, California 90095-1606, USA.

Gregory P. Dietl is at the Paleontological Research Institution, 1259 Trumansburg Road, Ithaca, New York 14850, USA.

Michael E. Hochberg is at the Institut des Sciences de I'Evolution, Université Montpellier II, CNRS, Place Eugéne Bataillon, 34095 Montpellier, France.

Dominic D. P. Johnson is in Politics and International Relations, University of Edinburgh, 15A George Square, Edinburgh EH8 9LD, UK.

Simon Levin is in the Department of Ecology and Evolutionary Biology, Princeton University, Princeton, New Jersey 08544, USA.

Elizabeth M. P. Madin is in the Department of Ecology, Evolution and Marine Biology, University of California at Santa Barbara, Santa Barbara, California 93106, USA.

Joshua S. Madin is in the Department of Biological Sciences, Macquarie University, Sydney, New South Wales 2109, Australia.

Elizabeth M. Prescott is at the Edmund A. Walsh School of Foreign Service, Center for Peace and Security Studies, Georgetown University, Washington DC 20007, USA.

Richard Sosis is in the Department of Anthropology, University of Connecticut, Storrs, Connecticut 06269-2176, USA.

Terence Taylor is at the International Council for the Life Sciences, 4245 North Fairfax Drive, Suite 625, Arlington, Virginia 22203-9220, USA.

John Tooby is at the Center for Evolutionary Psychology, University of California at Santa Barbara, Santa Barbara, California 93106, USA.

Geerat J. Vermeij is in the Department of Geology, University of California at Davis, One Shields Avenue, Davis, California 95616-8605, USA.

\section{Comments}

There are currently no comments.

Subscribe to comments

This is a public forum. Please keep to our Community Guidelines. You can be controversial, 
but please don't get personal or offensive and do keep it brief. Remember our threads are for feedback and discussion - not for publishing papers, press releases or advertisements. If you find something abusive or inappropriate or which does not otherwise comply with our Terms or Community Guidelines, please select the relevant 'Report this comment' link.

You need to be registered with Nature and agree to our Community Guidelines to leave a comment. Please log in or register as a new user. You will be re-directed back to this page.

Nature ISSN 0028-0836 EISSN 1476-4687

(C) 2010 Nature Publishing Group, a division of Macmillan Publishers Limited. All Rights Reserved. partner of AGORA, HINARI, OARE, INASP, CrossRef and COUNTER 